\title{
Development Framework for Agro-Based Industries in Secondary Cities of Sindh Province, Pakistan: SWOT Analysis of Ten-Year Perspective and Medium-Term Development Framework Plans
}

\author{
Saima Kalwar ${ }^{1,2, *}$, Melasutra Md Dali ${ }^{2, *}$ and Norhaslina Hassan ${ }^{3}$ \\ 1 Department of City and Regional planning, Mehran University of Engineering and Technology, \\ Jamshoro 76062, Pakistan \\ 2 Faculty of Built Environment, University of Malaya, Kuala Lumpur 50603, Malaysia \\ 3 Faculty of Arts and Social Sciences, University of Malaya, Kuala Lumpur 50603, Malaysia; \\ nhaslina@um.edu.my \\ * Correspondence: saima.kalwar@faculty.muet.edu.pk (S.K.); melasutr@um.edu.my (M.M.D.)
}

Received: 10 March 2018; Accepted: 10 April 2018; Published: 16 April 2018

\begin{abstract}
The study intended to explore planning strategies gaps in ten-year perspective and medium-term development framework plans for agro-based industrial development in secondary cities of Sindh Province, Pakistan. Document review and key informant interviews survey techniques were used for data collection. A total of 30 interviews were conducted from agro-based officials. The SWOT analysis technique was applied for data analysis. The results revealed the weaknesses of high priority for textile and sugar industries, lack of planning strategies for agro-based development in secondary cities, dependency on federal government for development funds and absence of finances to implement plans. The threats were unavailability of strategic agro-based infrastructure facilities in secondary cities, centralized planning system, cross border threats such as the war in Afghanistan and migration of Afghan refugees, weak law and order situation and diversion of development budget for defense activities. The study suggests decentralization of powers and robust planning strategies in the development plans to strengthen secondary cities of Sindh Province economically.
\end{abstract}

Keywords: secondary cities; planning strategies; agro-based industrial development; ten-year perspective plan; medium-term development framework; SWOT analysis; Sindh Province; Pakistan

\section{Introduction}

It is an entrenched reality that urban areas whether metropolitan or secondary cities are engines of regional economic growth [1-3]. Secondary cities and intermediate urban centers, especially, play a dynamic role in the economic development of a region. The consensus of policymakers and regional planners is that secondary cities serve as the regional service centers and are major contributors for rural development [4-6]. Secondary cities integrated into the national and regional economies tend to flourish and stimulate more economic growth and create job opportunities. Juan (2014) claimed that "secondary cities are the emerging engine of the rapid pace urbanization the world will experience in the forthcoming decades" [7] (p. 2).

It is also a well-established factor that agro-based industrial development plays a strategic role in the economic growth and development of a country [8]. Agro-based industries are potentially strong in providing farming and off-farm employment opportunities to rural and urban inhabitants [9]. Off-farm activities include processing, handling, packaging, transporting and marketing of agricultural products and by-products $[10,11]$. Therefore, agro-based industrial development has a significant 
impact on economic development in both urban and rural communities and ultimately leads towards regional development [8,9].

Agriculture sector is the backbone of Pakistan's economy. The major industries of Pakistan rely on wheat, rice and cotton production. The agriculture sector has a share of more than $20 \%$ in Pakistan's GDP. The sector also employs approximately $41 \%$ of the national labor force and provides sustenance to almost $67 \%$ of the national population [12].

The decline in agriculture production creates inflationary pressure and bottlenecks for Pakistan's economic development. Progressive agriculture development generates sound economic base and leads towards self-sustained growth [9]. Thus, developing competitive agro-based industries in urban areas is crucial for generating employment and income opportunities as well as brings local and regional economic development $[8,13]$.

Located in the southeast of Pakistan, Sindh Province is the most urbanized province of Pakistan with $48.8 \%$ urban population. The province has two metropolitan cities: Karachi and Hyderabad. There are also 148 secondary cities and small towns [14].

The Sindh Province is an agro-based region, with approximately $45 \%$ of the province's working population engaged in the agriculture and fishing sectors [12]. Most of Sindh Province's secondary cities were established either on the left or right bank of the Indus River: Kandkot, Sukkur, Sheikarpur, Larkanna, Jacobabad, Dadu, Jamshoro and Thatta are on the right bank of the River Indus, while Ghotki, Rohri Khairpur, NausheroFeroze Nawabshah Mirpurkhas and Sijawal are on the left bank of the River Indus. The surrounding rural areas of these secondary cities have agriculture and fisheries as their primary source of income [14].

According to Cities Alliance (2014) "a secondary city is a term most commonly used to describe the second-tier, or level, in the hierarchy of cities below the primary level" [15] (p. 2). The other terms used for secondary cities are second-tier cities and intermediate cities [5,15-17]. European Institute of Urban Affairs (2012) described secondary cities as "those cities outside the capital cities, whose economic and social performance is sufficiently important to affect the potential performance of the national and regional economy" [18] (p. 3).

Different researchers argued that the secondary cities development strategy play key role in raising both national and regional levels of prosperity by reducing the gap between urban and rural localities $[5,16,17,19]$. Richardson (1977) claimed that "the strategy of secondary city development attempts to strengthen urban-rural linkages via the development of agro-based industries and expansion in the production of agricultural inputs with respects to infrastructure" $[20,21]$ (p. 22).

"The growth of secondary cities strongly influences agricultural cropping patterns, the intensity of land use and the returns to agricultural investment in surrounding areas" [16] (p. 47). Additionally, these cities create demand for the goods produced in rural areas cottage industries [21,22]. David Satterthwaite also claimed that "secondary cities are the economic heart for large rural areas in the third world" [22] (p. 1). Thus, due to their integration with the rural hinterland, the secondary cities should have strong rural linkage [23].

Although the urban areas whether metropolitan or secondary cities are considered as the economic engines of a country, the general consensus of planners and policymakers is that secondary cities serves as the regional service centers and are major contributors for the rural development $[5,16,17,19,21]$. These statements revealed that secondary cities are the economic stimulators for both rural and urban areas compared to metropolitan cities, especially in agro-based countries. Therefore, reinforcement of the planning structure for the secondary cities will directly contribute to the rural and regional areas and their local economic development $[16,17]$. Consequently, if secondary cities are to be developed sustainably, then greater attention should be paid to planning strategies taken at all governmental levels for development and sustenance of these settlements [17].

It is clear from the above arguments given by other researchers that secondary cities development is a strategic tool to achieve agro-based economic development at regional level. Therefore, the planning strategies of central governments could play an important role in building a network of secondary 
cities [17]. This can be achieved through investing in the advancement of the trade diversification, large and small scale industrial sector as well as agricultural produce processing facilities. That may lead to the strong beneficial linkages with their rural hinterland [16,17].

However, unlike the situation in other developed and developing countries of Asia, the secondary cities and their role in the agro-based industrial development of regions is still a new topic in Pakistan and Sindh Province [4,24]. This raises the questions: Why are governmental bodies not taking initiatives for the agro-based development of these secondary cities? Moreover, if this trend continues, will the secondary cities of Sindh cease to exist?

Considering these factors, the study aimed to analyze and explore planning strategies gaps in the development plans of Pakistan prepared during 2001-2010 for agro-based industrial development in secondary cities of Sindh Province and the root-causes behind these gaps. The purpose for selecting this period was to explore the long-term and medium-term development plans strategies gaps to get the long and medium vision of the development framework of Pakistan regarding agro-based industrial development in secondary cities. Pakistan has a centralized system for the development plans for central and provincial government. The long-term plans (perspective plans/vision plans) are prepared for 10-25 years, the medium-term plans (development plans) are developed for 3-5 years and the short-term plans (annual plans) are prepared for one year. The long-term and medium-term plans are developed by Planning Commission, Ministry of Planning Development and Reforms, Government of Pakistan, in collaboration with the Planning and Development Department of Provincial Governments [25].

Therefore, this study conducted research on ten-year perspective (TYP) and medium-term development framework (MTDF) plans planning strategies to uplift the agro-based industrial development in secondary cities of Sindh Province by using SWOT analysis technique. The ten-year perspective plan (2001-2010) had 10 years long vision and 3 years medium vision [26]. The MTDF plan had medium-term vision. In 2004, the federal government had replaced the Five-Year Development Plan with Medium-Term Development Framework (MTDF). The first MTDF of Pakistan was launched in 2005 [25,27].

Although different researchers have emphasized that secondary cities are the vital players for bringing local, regional, national and global development $[6,16,17,19,28-34]$, secondary cities are still a "missing middle" despite their increasing importance $[3,5,16,17,35]$.

Especially, there is still lack of research that would allow a broader assessment of the importance secondary cities regarding agro-based industrial development in Pakistan and Sindh Province context $[4,24]$. According to reviewed literature, it was also observed that still no study had incorporated agro-based industrial development, secondary cities of Sindh Province and planning strategies of ten-year perspective and MTDF plans of Pakistan together. Through the current research this gap can be filled. This study may also serve as a guide for planners and policymakers in strengthening the agro-based industrial development of secondary cities of Sindh Province.

This paper is divided into six sections: Sections 2 and 3 describe the background information about the system of secondary cities of Sindh Province and importance of agro-based industrial development in Sindh Province. Section 4 states the methodology employed for data collection and analysis. Section 5 presents the results produced through SWOT analysis and content analysis. The paper later concludes by discussing the results obtained in Section 6, offering conclusions and recommendations, and stating the limitation of this study.

\section{System of Secondary Cities in Sindh Province}

Sindh Province is the most urbanized province in Pakistan. Figure 1 presents the major cities of Sindh Province. The province has more than 20 secondary cities such as Sukkur, Larkana, Nawabshah, Kashmore, Jacobabad, etc. Among these 20 cities, 18 are sub-regional secondary cities (district headquarter cities). The remaining 128 cities are small cities and towns [14]. 


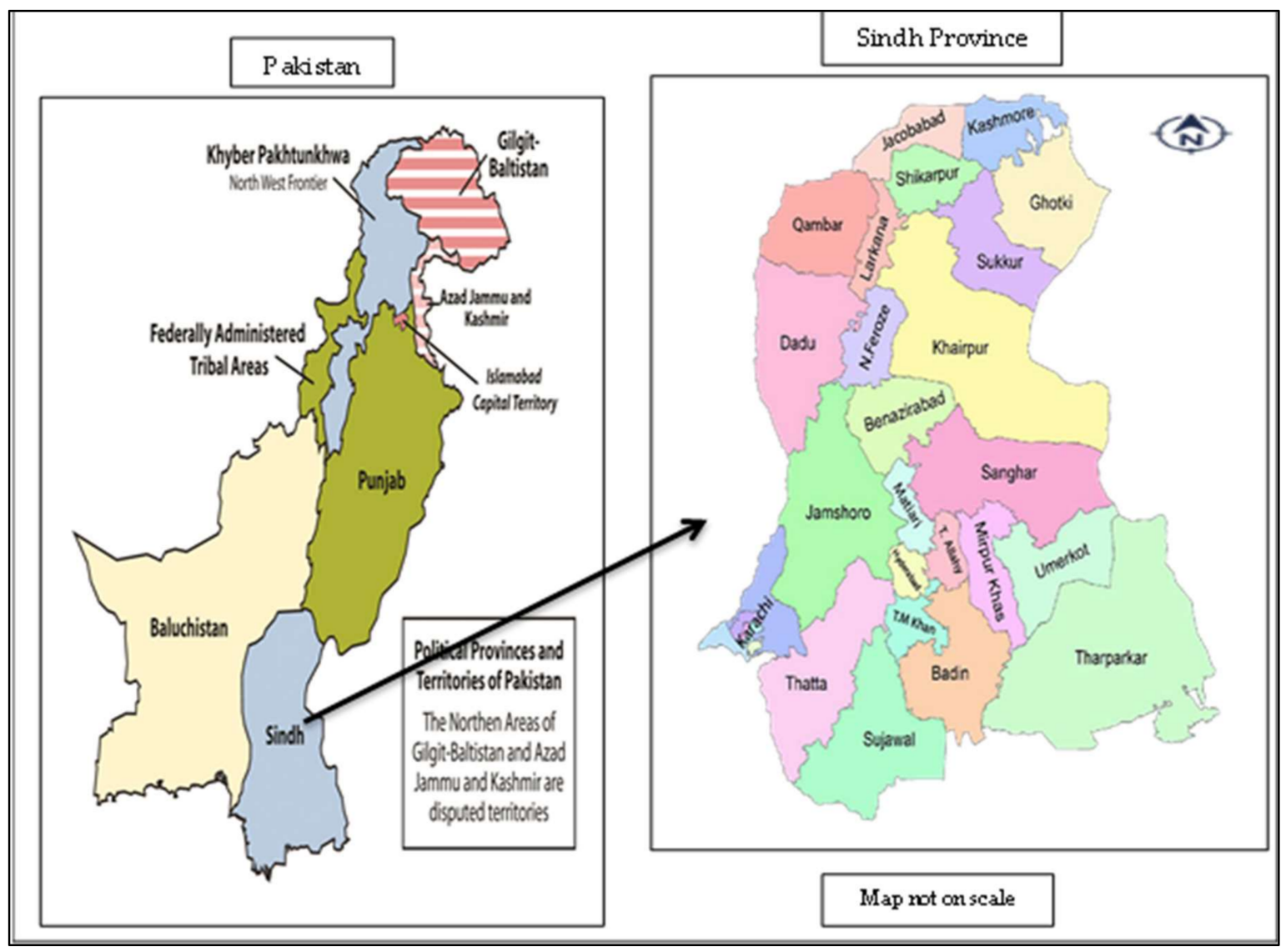

Figure 1. Map of Pakistan and Sindh Province.

According to population census, 2017, Sindh Province shared 23\% of the country's population and $17.7 \%$ of land area. The province consisted of $48.9 \%$ urban population, accounting for $32.5 \%$ of Pakistan's urban population. Immigrants from other provinces of Pakistan and the accommodation of migrants from other countries such as Bangladesh, Burma and Afghanistan have become one of the reasons that cause the high population within that area. Those migrants come looking for social and economic opportunities. Interestingly, most of those immigrants settle down in Karachi City, which represents $64 \%$ of the urban population in Sindh Province and $21.7 \%$ of the urban population in Pakistan [12].

Figure 2 shows that $64 \%$ of the urban population in Sindh Province is living in Karachi City in 2015. Hyderabad City, the second largest city within the province as well as the divisional and provincial central city, represents only $6.67 \%$ of the urban population. There are only $30 \%$ of urban population which are living in secondary and small cities of the province. Sukkur City, the third largest city and the central hub for Northern Sindh (Upper Sindh), only has a $\%$ share of population. Larkana and Mirpurkhas Cities, which are the fourth and fifth largest cities regarding population, also share $2 \%$ of urban population of Sindh Province [12].

Obviously, an imbalance system of cities is reflected in Sindh Province. Everyone knows the people from rural and small areas move to metropolitan cities in search of employment opportunities. Obviously, Karachi City is rich in generating skilled and unskilled employment to cater to the needs of its local inhabitants and migrated population. However, why is the same situation not happening in secondary cities? Before finding out the causes behind all these phenomena, it is better to first present the scenario of agro-based industrial development in Sindh Province. 


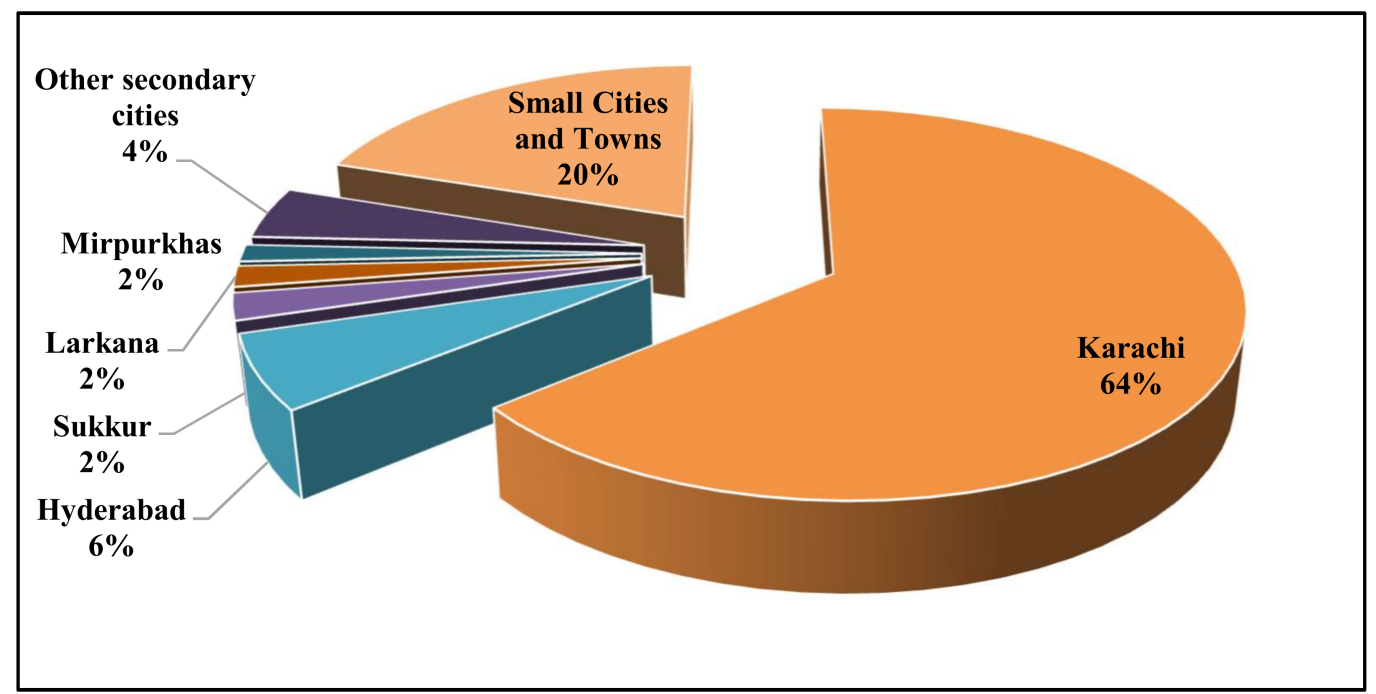

Figure 2. Urban Population Share of Major Cities of Sindh Province, 2017.

\section{Agro-Based Industrial Development in Sindh Province}

Sindh Province is located in the southeast of Pakistan. Sindh is an agro-based region. Sindh Province's principal natural resources are arable land and water. Agriculture sector plays a vital role in the economic development of Sindh and Pakistan. Sindh Province is also a major contributor to national economic and development growth. According to the Sindh Board of Investment (SBI), the province produces approximately $33 \%$ of the national GDP. The province houses $54 \%$ of Pakistan's textile units, $45 \%$ of sugar mills and, overall, a third of the national large scale manufacturing capacity. Accordingly, it amasses $70 \%$ of country's income tax and $62 \%$ of sales tax [25].

As described above, most of the secondary cities in Sindh are established either on the left or right bank of Indus River. The surrounding rural areas of these secondary cities have agriculture as their primary source of income [32]. Therefore, the development of agro-based manufacturing activities is vital in secondary cities and their regions, where the population is heavily dependent on the agriculture sector. Vachal (2005) also emphasized that "the role of secondary and small cities is very crucial for the government institutions and policy designers in crafting economic growth strategies for the agricultural regions" [36] (p. 4).

Based on the data provided by Ministry of Labor, Manpower and Overseas Pakistanis Division (MLMD), Government of Pakistan (2017) Agriculture, Forestry, Hunting and Fisheries (AFHF) has maintained as the major employment industry for Sindh Province. If we observe the employment trends of major industry divisions in Sindh Province, during ten-year perspective plan (2001-2010) and MTDF (2005-2010), the AFHF sector was employing approximately $45 \%$ working population of the province (refer to Figure 3). That trend continued in 2015 and AFHF sector maintained employing more than $45 \%$ of working population of Sindh Province [37].

During the studied development planning period (2001-2010), it was also observed from the data provided by the ministry that agriculture sector caters to more than $69 \%$ of employment needs of rural areas of Sindh during 2001-2005. That share increased to 75\% in 2010 (refer to Figure 4). However, this sector showed a decline of approximately 6\% during 2010-2015. However, it continued to employ $69 \%$ of working population of Sindh rural areas [37]. It is clear from the available statistics that agro-based is the major employment sector of Sindh Province and its rural areas. Therefore, any rise and fall in this sector can directly reflect the economy of the province. 


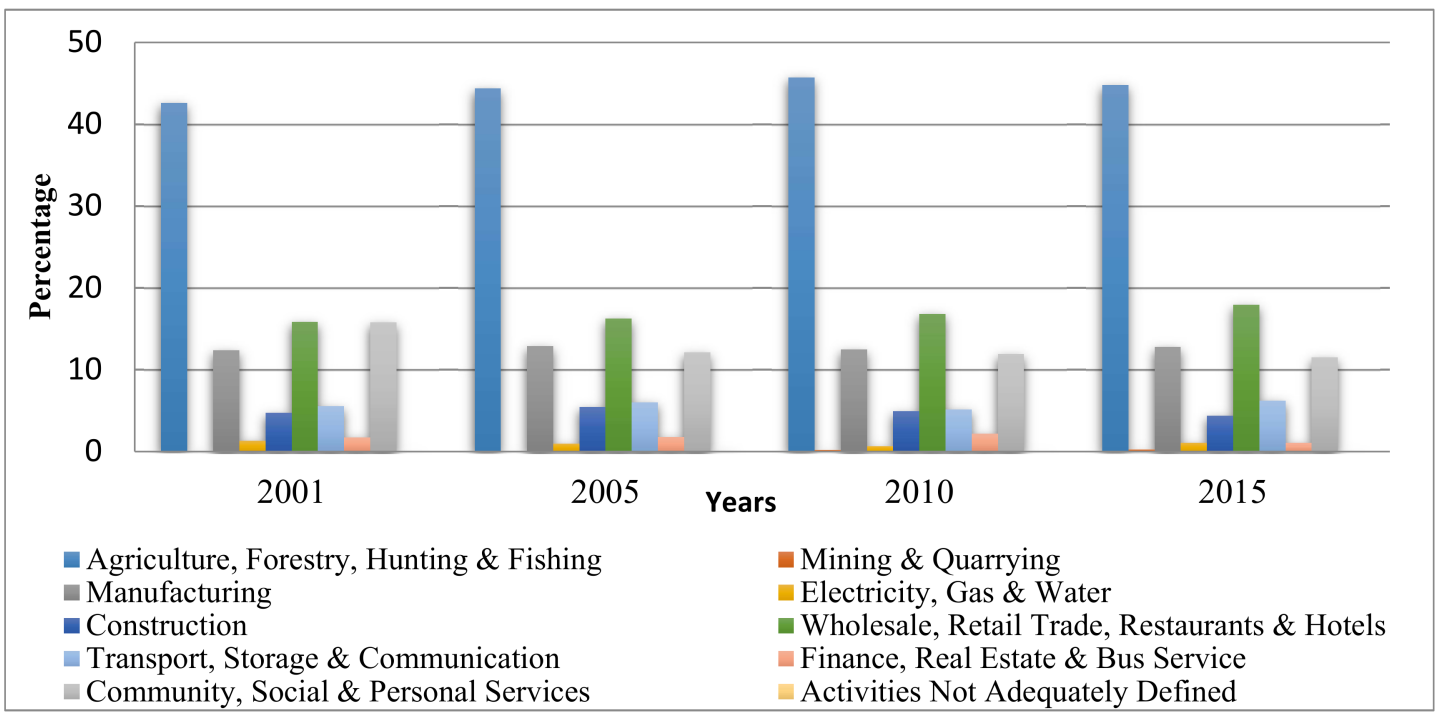

Figure 3. Employed Population of Sindh Province in Key Industry Divisions, 2001-2015.

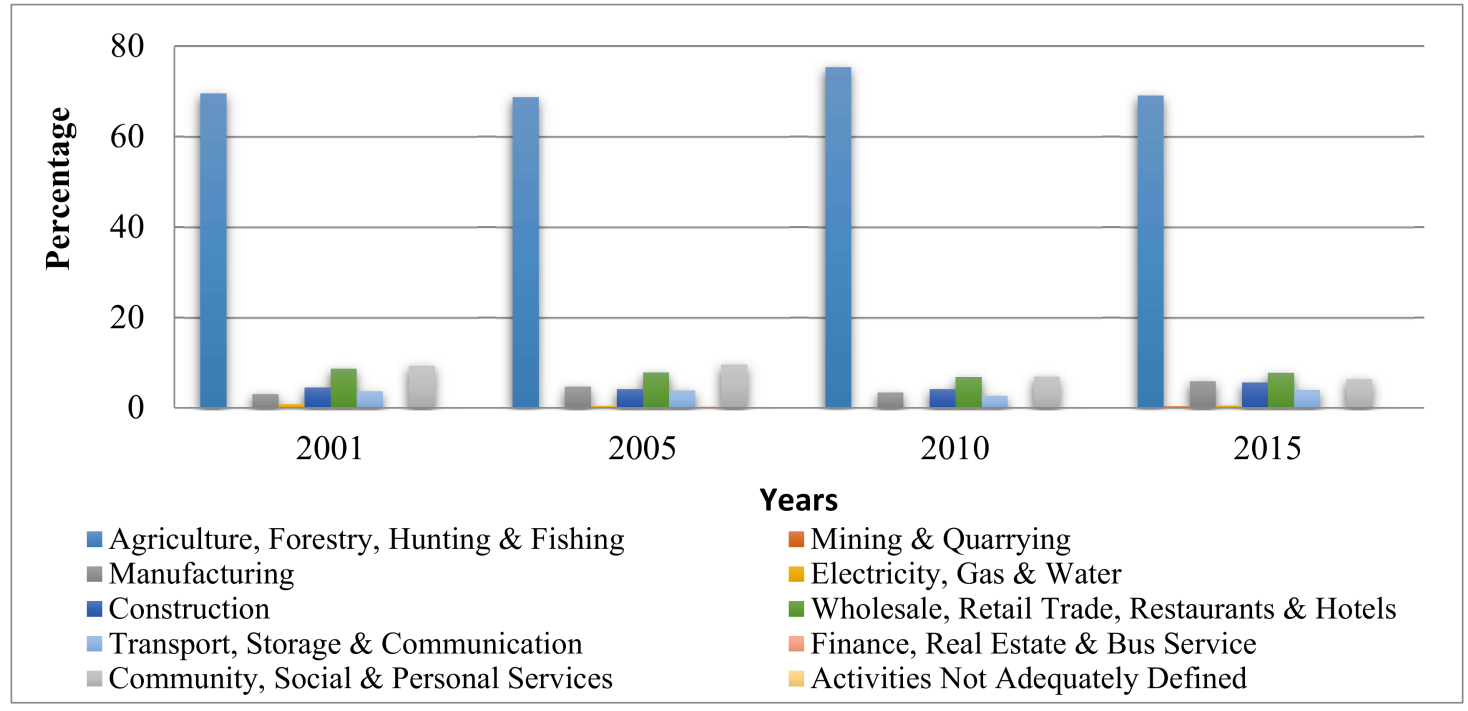

Figure 4. Employed Population of Sindh Rural Areas in Key Industry Divisions, 2001-2015.

Throughout the employment trends of Sindh urban areas during the same planning period, manufacturing was the major employment sector in Sindh urban areas along with Wholesale, Retail, Trade, Restaurant and Hotel (WRTRH) and Community, Social and Personal Services (CSPS) sectors (refer to Figure 5). The manufacturing sector had an employment share of $24.25 \%$ in 2001, which increased to $25.36 \%$ in 2010 . However, this industry share declined to $23.75 \%$ in 2015 , which is similar to the agriculture sector in Sindh [37].

The above statistics also show that surrounding rural settlements of the secondary cities of Sindh Province are mostly dependent on farming activities for their economic sustenance. Therefore, these secondary cities should have a strong agro-based industrial system to fully utilize the agricultural products and by-products. 


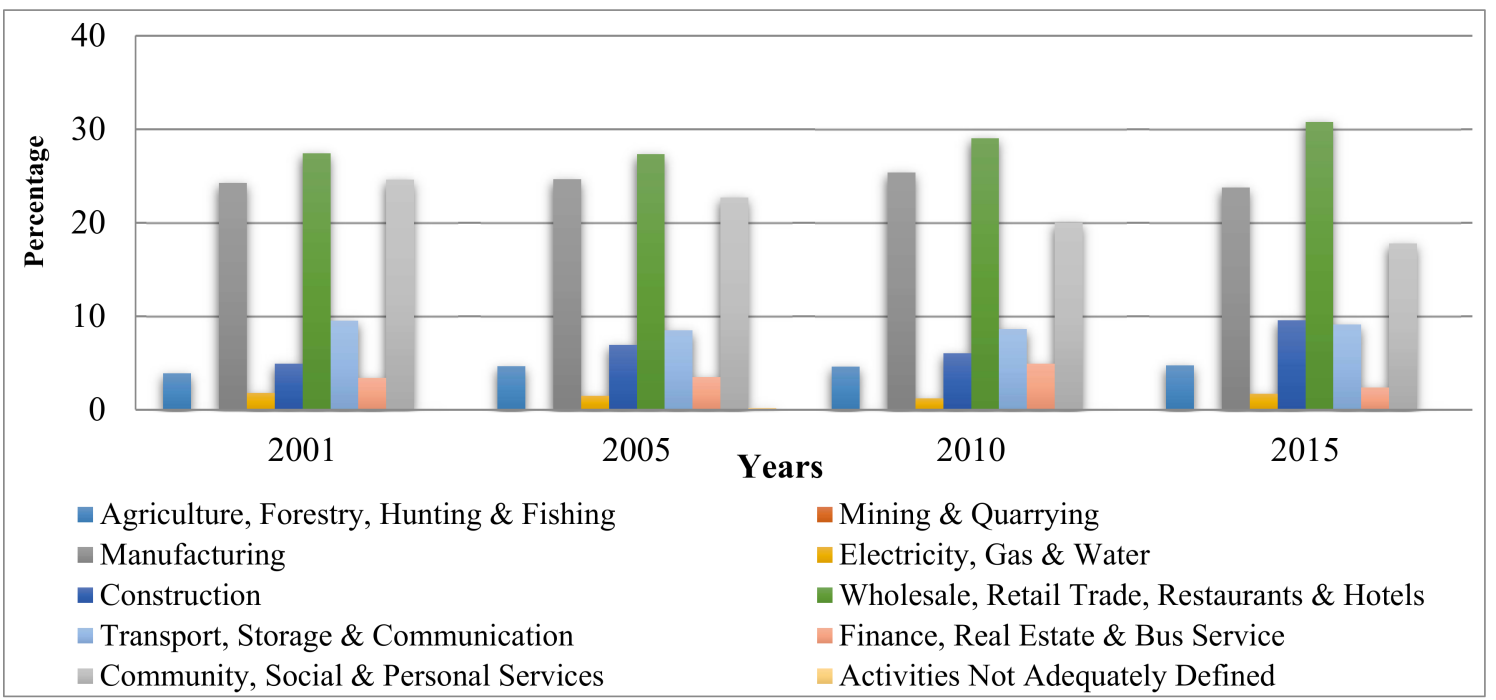

Figure 5. Employed Population of Sindh Urban Areas in Key Industry Divisions, 2001-2015.

Although there are four industrial zones, one export processing zone, 17 Sindh Industrial Trading Estate (SITE) and 14 Small Industrial Estates (SIE) in Sindh Province, interestingly, more than 70\% of industrial units are functioning at or near Karachi and Hyderabad cities. There are one export processing zone, four industrial zones and eight SITE areas within and nearby Karachi and Hyderabad cities. These sites cater to the employment needs of Karachi and Hyderabad cities. Only one SITE area and one SIE each are located in Sukkur and Larkana Cities. One SIE each was also established in Shikarpur and Kandhkot Cities [38]. The government also initiated the development of industrial estates in Larkana and Nawabshah secondary cities, but their development was halted due to political reasons. The lack of industrial units (40\%) in those SITE and SIE areas have caused the high demand for employment opportunities in secondary cities [38].

It is clear from above statistics that Sindh Province has industrial sites for the agro-based industries. However, most were established to create employment opportunities for Karachi and Hyderabad metropolitan cities. Only two SITE and four SIE areas were established in secondary cities of Sindh Province, which are of course not sufficient to cater to the employment needs of the secondary cities and their surrounding rural areas. If governmental bodies are establishing industrial estate in metropolitan cities, then why are they not initiating the same programs for secondary cities? Considering these issues, this study aimed to identify the planning strategies gaps in the Ten-Year Perspective (TYP) and Medium-Term Development Framework (MTDF) plans developed during 2001-2010. The next part discusses the methodology the study adopted for this research.

\section{Methodology}

This study was intended to explore the planning strategy gaps in the national ten-year perspective and MTDF plans for the agro-based industrial development of the secondary cities of the Sindh Province along with the reasons and influencing forces behind all that phenomena. The research is about plans and the planning system and is of exploratory nature. The exploratory study is a valuable way to reveal more insights and ideas to discover the real nature of the issue [39,40]. As the nature of the research was exploratory, the study used qualitative research methodology [40,41]. Qualitative research constructs a general focus of the investigation, which guides towards the discovery of what needs to be known $[42,43]$. The following methodology was performed during data collection and data analysis. 


\subsection{Data Collection}

This study employed both document review and key informant interviews techniques for data collection [44-46]. The documents review method was adopted for two purposes: (1) to provide the basis and background for the interview guide; and (2) to serve as propositions at the analysis stage of the research [45]. Therefore, the researchers had reviewed the ten-year perspective and medium-term development framework plans to have the in-depth information about these plans for researcher's clear perception.

Based on purpose un-probability sampling technique [47,48], 30 formal interviews were conducted with officials of agro-based sector to gather their views about the strengths, weaknesses, opportunities and threats of targeted plans (refer to Table 1). The interviews emphasize reliability by comparing the accuracy of the answers given by respondents [43,44] provided the questions for each respondent were same. The purpose of this interview was to enable every respondent to have the same understanding of the research questions and allow them to describe their opinions freely. Those interviews also offer a more comprehensive view of an issue [47]. The open-ended questions format was applied to collect the detail reviews of the key informants about the plans. The open-ended question format allows the respondents to answer freely and reflect their opinions regarding the subject $[46,47]$.

Table 1. List of Key Informant Interviewees.

\begin{tabular}{ccc}
\hline Economic Sector & Designation & No of Interviewees \\
\hline & Director General Agriculture, Sindh & 2 \\
& Director Agriculture & 5 \\
& Chairman Chamber of Commerce & 3 \\
Chairman SITE, Sindh & 1 \\
Agro-based & Chairman SIE, Sindh & 1 \\
& Professor Agriculture & 2 \\
Deputy Director & 5 \\
& Assistant Director Agriculture & 5 \\
Site Officers & 3 \\
Site Officers & 3 \\
\hline
\end{tabular}

For the validity and reliability of research, the bottom-up approach was used for the conduct of key informant interviews. The list of officials was taken from Agriculture Department and Sindh Industrial Trading Corporation, Government of Sindh. The interviews were conducted from the Assistant Directors and Site Officers working in secondary cities to the higher officials (Director General and Directors) of Sindh Government to get rigorous and unbiased research findings.

Ethical consideration is vital in qualitative research to safeguard and protect the participant [49]. Thus, consent was obtained from the respondents prior to conducting the interview.

The employment data were gathered from the labor force statistics, Pakistan Bureau of Statistics, Ministry of Labor, Manpower and Overseas Pakistani Division, Government of Pakistan.

\subsection{Data Analytical Approach}

The data were analyzed through SWOT analysis techniques. Many researchers claimed that SWOT analysis (strengths, weaknesses, opportunities, and threats) is a key feature of the planning analysis as a basis for devising action strategies to achieve goals and objectives in priority areas [50-52]. Nvivo software was employed to process the data and to avoid biased research results. NVivo is capable of managing, accessing, and keeping a perspective on the entire data without losing focus on its richness and that is the essence of qualitative research [53]. The deductive content analysis technique was used in NVivo to get the SWOT of the ten-year perspective and medium-term development 
framework plans based on the views given by key informant. This analytical technique is widely used in qualitative research [54-56].

\section{Results}

The results of strengths, weaknesses, opportunities, and threats of ten-year perspective and medium-term development plans based on the responses of key informants are described below.

\subsection{Ten-Year Perspective Plan (2001-2010)}

Table 2 presents the strengths, weaknesses, opportunities and threats of ten-year perspective plan based on the views of the agro-based key informants. In Table 2, SWOT analysis has classified the point listed in ten-year perspective plan (2001-2010) for agro-based industrial development into above mentioned four different groups (Strengths, Weaknesses, Opportunities and Threats).

Table 2. S-WOT Analysis of Ten-Year Perspective Development Plan (2001-2010) for Agro-Based Industrial Development.

\begin{tabular}{|c|c|}
\hline Strengths & Weaknesses \\
\hline $\begin{array}{l}\text { a Expansion of agro-based industries through the } \\
\text { development of small and medium labor-intense } \\
\text { industries to offer more employment opportunities } \\
\text { a Establishment of agro-based by-product industries } \\
\text { a Coordination between *PCSIR and industries } \\
\text { a Establishment of *SMEDA for providing technical } \\
\text { assistance to small and medium industries } \\
\text { a Establishment of Industrial Support Centers for } \\
\text { agro-based and small scale industries } \\
\text { a Tax relief in customs on machinery }\end{array}$ & $\begin{array}{l}\text { Q Main focus on textile and sugar industries } \\
\text { a Heavy unpaid loans on textile and sugar industries } \\
\text { were written-off } \\
\text { a Reliance on federal institutions for the release of } \\
\text { funds to implement plans } \\
\text { Q Lack of institutional collaboration in federal and } \\
\text { provincial organizations } \\
\text { Q Lack of finances to implement plans and programs }\end{array}$ \\
\hline Opportunities & Threats \\
\hline $\begin{array}{l}\text { Q Development of farm to market roads } \\
\text { a Development and improvement of roads and other } \\
\text { infrastructure services in industrial estates } \\
\text { a Export industries instead of local need based } \\
\text { industries } \\
\text { a Revitalization of *sick units } \\
\text { a Establishment of Khushali Bank to provide loans to } \\
\text { unemployed persons for setting agro-based and } \\
\text { cottage industries }\end{array}$ & $\begin{array}{l}\text { a Inadequate agro-based infrastructure facilities in } \\
\text { secondary cities to cope with the demand } \\
\text { a Centralized planning system } \\
\text { a Cross-border war in Afghanistan } \\
\text { a Migration of Afghani people to Pakistan } \\
\text { a Heavy burden on Pakistan's economy to } \\
\text { accommodate Afghan refugees } \\
\text { a Worsened law and order conditions in Northern } \\
\text { areas of Pakistan due to the presence of Afghan } \\
\text { refugees } \\
\text { a Diversion of sanctioned development budget for } \\
\text { defense activities and settlement of Afghani people }\end{array}$ \\
\hline
\end{tabular}

*SMEDA: Small and Medium Enterprises Development Authority, Government of Pakistan; *PCSIR: Pakistan Council of Scientific and Industrial Research; *Sick Units: The units which existed for at least five years and had accumulated losses equal to or exceeding its entire net worth at the end of any financial year.

\subsection{Medium-Term Development Framework Plan (2005-2010)}

Table 3 represents the SWOT analysis of MTDF (2005-2010) for agro-based industrial development based on the views given by agro-based experts. All the strengths, weaknesses, opportunities and threats for the medium-term development framework (2005-2010) for agro-based development are summarized in Table 3. 
Table 3. SWOT Analysis of Medium-Term Development Framework (2005-2010) for Agro-Based Industrial Development.

\begin{tabular}{|c|c|}
\hline Strengths & Weaknesses \\
\hline $\begin{array}{l}\text { Establishment of textile and sugar industries in } \\
\text { different cities } \\
\text { a Up-gradation in technology and business skills } \\
\text { through the establishment of common technical } \\
\text { support centers in industrial areas } \\
\text { a Reforming of legal, taxation and institutional } \\
\text { framework }\end{array}$ & $\begin{array}{l}\text { a The plan mainly focused on large scale industries } \\
\text { such as textiles and sugar industries } \\
\text { a Lack of planning strategies for the development } \\
\text { and expansion of light and medium agro-based } \\
\text { industrial development } \\
\text { a Reliance on federal government for the release of } \\
\text { capital for implementation of programs } \\
\text { a Lack of institutional collaboration in federal and } \\
\text { provincial organizations } \\
\text { a Government failed to implement these plans and } \\
\text { programs due to unavailability of finances }\end{array}$ \\
\hline Opportunities & Threats \\
\hline $\begin{array}{l}\text { a Provision of infrastructure, self-contained utilities } \\
\text { a Improvement in market access and product } \\
\text { information in global context } \\
\text { a Improving access to financial resources and services } \\
\text { through the development of Khushali Banks } \\
\text { Enhancement of export-oriented industries in } \\
\text { different cities }\end{array}$ & $\begin{array}{l}\text { a Weak strategic infrastructure facilities required for } \\
\text { agro-based development in secondary cities } \\
\text { a Centralized planning system } \\
\text { a Continuing war in Afghanistan } \\
\text { a Migration of Afghani refugees in Pakistan } \\
\text { a Worse law and order conditions due to the presence } \\
\text { of Afghan refugees } \\
\text { a Diversion of development budget for the } \\
\text { accommodation of Afghan refugees and defense } \\
\text { activities } \\
\text { a Heavy burden on Pakistan economy to } \\
\text { accommodate Afghan refugees }\end{array}$ \\
\hline
\end{tabular}

\subsection{SWOT Analysis Results of Ten-Year Perspective and MTDF Plans}

The study conducted key informant interviews with 30 agro-based officials in open-ended questionnaire form [41,43]. The gathered views of the agro-based key informants about the SWOT of ten-year perspective and medium-term development plans were then analyzed through deductive content analysis method in NVivo software. The ABI Cases 1-30 represent the identity of every agro-based key informant and the views given by them. The results of strengths, weaknesses, opportunities, and threats of ten-year perspective and MTDF plans for agro-based industrial development based on the responses of key informants are described below:

\subsubsection{Strengths of Ten-Year Perspective and MTDF Plans}

The ten-year-perspective and MTDF plans presented a total of four strengths for agro-based industrial development (see Table 4). Figure 6 presents the cognitive map of the collective strengths of ten-year perspective and MTDF plans for agro-based industrial development.

Table 4. Content Analysis Coding Results for Strengths of Ten-Year Perspective and Medium-Term Development Framework Plans for Agro-based Industrial Development.

\begin{tabular}{lccc}
\hline \multicolumn{1}{c}{ Strengths (Sub-Themes) } & Development Plans & No of Respondents & Percentage $(\mathbf{n} \times \mathbf{1 0 0 / 3 0 )}$ \\
\hline $\begin{array}{l}\text { Establishment of agro-based industries } \\
\text { in secondary cities and rural areas }\end{array}$ & TYP & 27 & 90 \\
\hline Establishment and up-gradation & TYP & - & - \\
of textile and sugar industries & MTDF & 26 & - \\
\hline Development of technical & TYP & 27 & 86.67 \\
assistance centers and organizations & MTDF & 24 & 90 \\
\hline Improvement in legal and & TYP & 27 & 90 \\
taxation system & MTDF & 29 & 96.67 \\
\hline
\end{tabular}




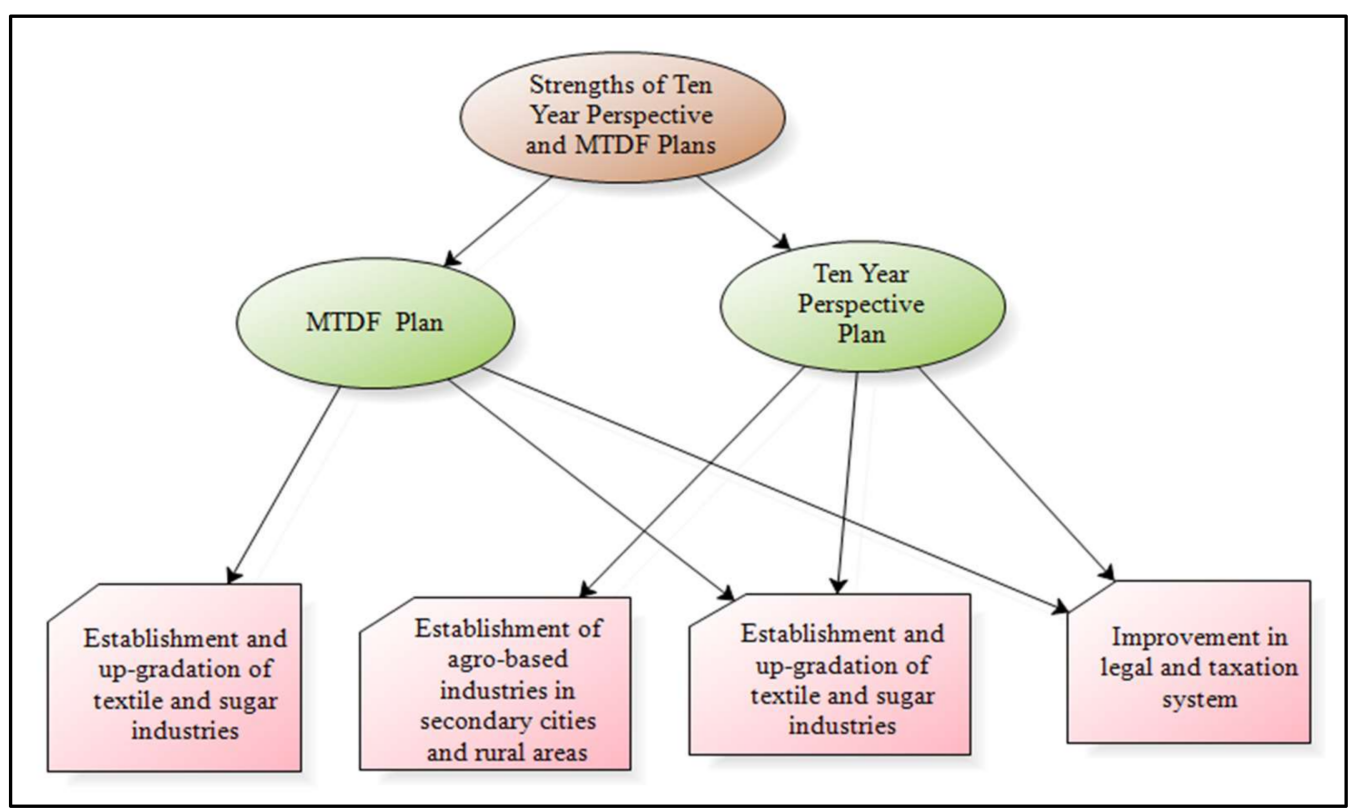

Figure 6. Cognitive Map of Strengths of Ten-Year Perspective and MTDF Plans for Agro-Based Industrial Development.

The strengths of both development plans for agro-based industrial development include:

1. Ninety percent of key informant claimed that the ten-year perspective plan presented planning strategies for the establishment of agro-based industries in secondary cities (see Table 4 and Figure 6). In this regard, the ten-year perspective plan emphasized the establishment of small and medium scale labor intensive industries to increase employment opportunities (ABI Cases 14; 20; 29).

2. According to the responses of more than $86 \%$ of interviews, the medium-term development framework plan suggested strategies for the establishment and upgradation of textile and sugar industries and the introduction of value addition in sugar products for domestic and export purposes (ABI Cases 6; 20) (see Table 4 and Figure 6).

3. The results revealed that more than $80 \%$ of key informant interviews responded that both development plans presented strategies for the establishment of technical assistance centers to strengthen institutionalized dissemination of information about acceptable export design and suitable technologies (see Table 4 and Figure 6). In this regard, the ten-year perspective plan established Technical Support Centers, and Small and Medium Enterprises Development Authority (SMEDA) to provide technical assistance to small and medium industries (ABI Cases 7; 9; 29). The MTDF suggested the establishment of Technology Support Centers in industrial areas for upgradation in technology and business skills (ABI Cases 16; 18; 22).

4. More than $90 \%$ of officials responded that both development plans suggested that there should be an improvement in legal and taxation system (see Table 4 and Figure 6). The ten-year perspective plan exempted $10 \%$ of customs duties from agro-based industries (ABI Cases 5; 15). The MTDF suggested that institutional, legal, taxation framework should be improved (ABI Cases 4; 10; 23).

\subsubsection{Weaknesses of Ten-Year Perspective and MTDF Plans}

The analysis of the gathered data revealed two types of planning strategies weaknesses in ten-year perspective and MTDF plans. Those were weaknesses for agro-based industrial development and weaknesses in the planning system. The details about the types of weaknesses in each plan for the 
agro-based industrial sector based on the responses of the key informant interviewees are described in Table 5 and Figure 7.

Table 5. Content Analysis Coding Results for Weaknesses of Ten-Year Perspective and Medium-Term Development Framework Plans for Agro-Based Industrial Development.

\begin{tabular}{|c|c|c|c|c|}
\hline $\begin{array}{l}\text { Weaknesses } \\
\text { (Main-Themes) }\end{array}$ & Weaknesses (Sub-Themes) & $\begin{array}{l}\text { Development } \\
\text { Plans }\end{array}$ & $\begin{array}{c}\text { No of } \\
\text { Respondents }\end{array}$ & $\begin{array}{l}\text { Percentage } \\
(n \times 100 / 30)\end{array}$ \\
\hline \multirow{4}{*}{$\begin{array}{l}\text { Weaknesses in TYP } \\
\text { and MTDF plans }\end{array}$} & \multirow{2}{*}{$\begin{array}{l}\text { Priority was given to the } \\
\text { development of textile and } \\
\text { sugar industries in Karachi and } \\
\text { other metropolitan cities }\end{array}$} & TYP & 24 & 80 \\
\hline & & MTDF & 24 & 80 \\
\hline & \multirow{2}{*}{$\begin{array}{l}\text { Lack of planning strategies for } \\
\text { the development and expansion } \\
\text { of light and medium agro-based } \\
\text { development in secondary cities }\end{array}$} & TYP & - & - \\
\hline & & MTDF & 25 & 83.33 \\
\hline \multirow{6}{*}{$\begin{array}{l}\text { Weaknesses Due to } \\
\text { Planning System of } \\
\text { Pakistan }\end{array}$} & \multirow{2}{*}{$\begin{array}{l}\text { Power of federal government } \\
\text { for the execution of economic } \\
\text { development plans }\end{array}$} & TYP & 22 & 73.33 \\
\hline & & MTDF & 23 & 76.67 \\
\hline & \multirow{2}{*}{$\begin{array}{l}\text { Lack of coordination between } \\
\text { federal and provincial } \\
\text { organizations }\end{array}$} & TYP & 23 & 76.67 \\
\hline & & MTDF & 23 & 76.67 \\
\hline & \multirow{2}{*}{$\begin{array}{l}\text { Unavailability of funds for the } \\
\text { implementation of plans }\end{array}$} & TYP & 21 & 70 \\
\hline & & MTDF & 22 & 73.33 \\
\hline
\end{tabular}

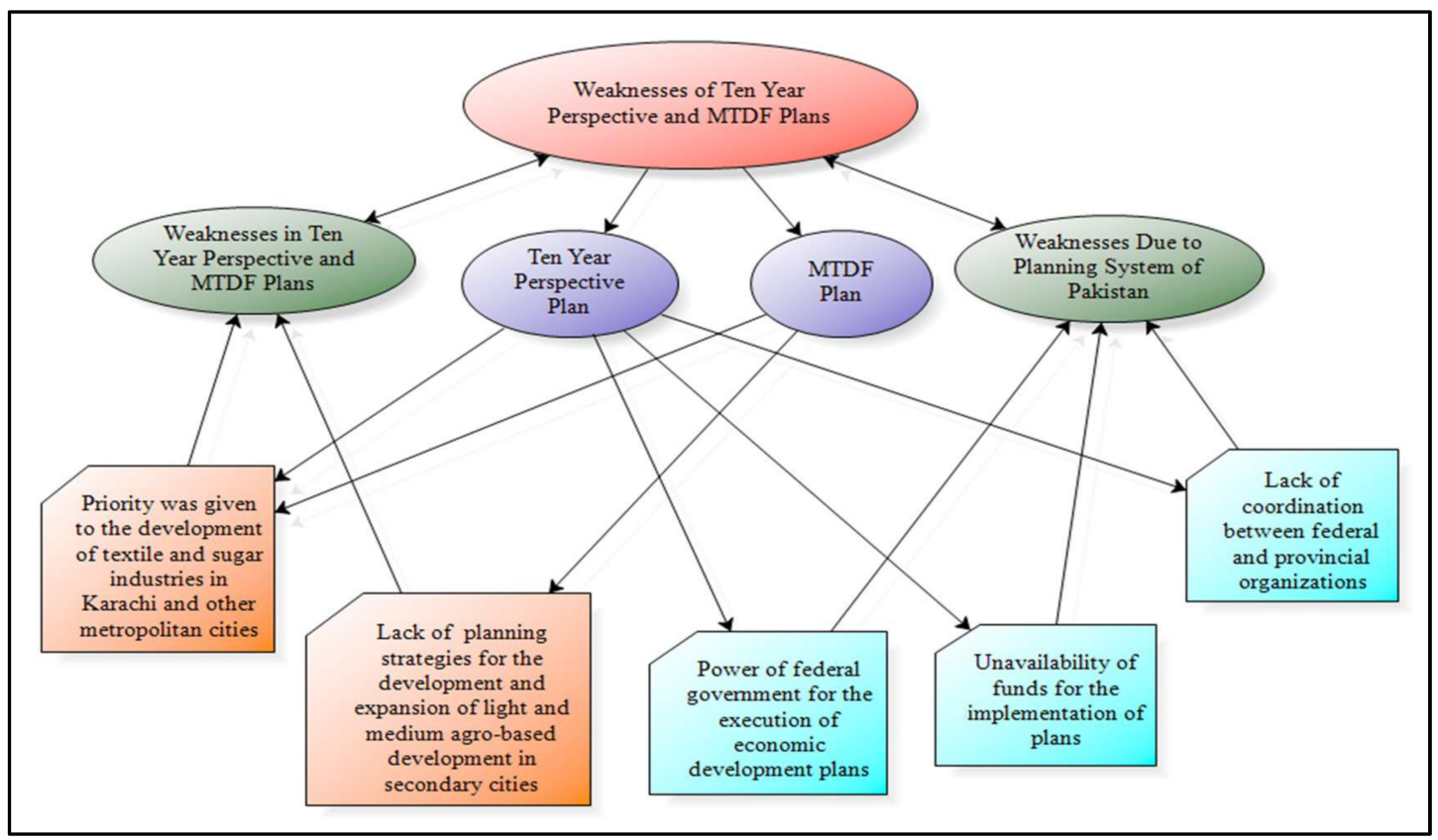

Figure 7. Cognitive Map of Weaknesses in Ten-Year Perspective and MTDF Plans for Agro-based Industrial Development. 
1. Weaknesses for Agro-Based Industrial Development

The results revealed two types of weaknesses in ten-year perspective and medium-term development framework plans for agro-based industrial development (see Table 5 and Figure 7). The weaknesses of both development plans for agro-based industrial development include:

i. Eighty percent of agro-based key informants responded that both plans gave priority to the development of textile and sugar industries (see Table 5 and Figure 7). The major part of the agro-based development budget was allocated for the development of textile and sugar industries (ABI Cases $7 ; 21 ; 30)$. The ten-year perspective plan also offered the credit facilities for the establishment of textile and sugar industries (ABI Case 5). The heavy taxes were also written-off for textile and sugar industries (ABI Case 10). The plan did not offer those opportunities for medium and small industrial development (ABI Case 15).

ii. More than $83 \%$ of key informants claimed that the MTDF plan failed to present planning strategies for the small and medium agro-based development in secondary cities (ABI Cases 8; 12; 19) (see Table 5 and Figure 7).

2. Weaknesses in the Planning System

The analysis of interview data revealed three types of planning system weaknesses present in ten-year perspective and medium-term development framework plans for the agro-based sector (see Table 5 and Figure 7). The weaknesses of both development plans due to planning system include:

i. More than $73 \%$ agro-based of key informants claimed that, due to the centralized planning system, all generated revenue and taxes go to the federal accounts. Therefore, one of the major weakness behind the implementation of development plans was the dependency of the provincial institutions on the federal government for the release of finance for implementation (ABI Cases 1; 14; 30) (see Table 5 and Figure 7).

ii. Due to the centralized planning system, federal organizations play an active role in the preparation of all development plans. The provincial governments do not have the autonomy to develop and implement provincial development plans (ABI Cases 3; 15; 30). Due to this planning gap, more than $73 \%$ of agro-based officials believed there is lack of coordination between federal and provincial organizations for the preparation and execution of development plans (ABI Cases 8; 9; 25) (see Table 5 and Figure 7).

iii. More than $70 \%$ of key informants claimed that the federal government released the development funds only for those programs which were favorable for them (see Table 5 and Figure 7). Therefore, during ten-year perspective and medium-term development framework plans, the federal government did not had finances to implemented most of the programs due to cross-border threats (ABI Cases 2; 7; 15).

\subsubsection{Opportunities of Ten-Year Perspective and MTDF Plans}

The ten-year perspective and MTDF plans presented five opportunities for agro-based industrial development, as shown in Table 6. Figure 8 presents the cognitive map of ten-year perspective and MTDF plans for agro-based industrial development.

Table 6. Content Analysis Coding Results of Opportunities for Ten-Year Perspective and Medium-Term Development Framework Plans for Agro-based Industrial Development.

\begin{tabular}{lccc}
\hline Opportunities (Sub-Themes) & Development Plans & No of Respondents & Percentage $(\mathbf{n} \times \mathbf{1 0 0 / 3 0 )}$ \\
\hline Development of export & TYP & 24 & 80 \\
processing industries & MTDF & 23 & 76.67 \\
\hline
\end{tabular}


Table 6. Cont.

\begin{tabular}{lccc}
\hline \multicolumn{1}{c}{ Opportunities (Sub-Themes) } & Development Plans & No of Respondents & Percentage $(\mathbf{n} \times \mathbf{1 0 0 / 3 0 )}$ \\
\hline Provision and improvement of & TYP & 18 & 60 \\
infrastructure facilities & MTDF & 27 & 90 \\
\hline \multirow{2}{*}{ Provision of credit facilities } & TYP & 27 & 90 \\
& MTDF & 25 & 83.33 \\
\hline \multirow{2}{*}{ Revitalization of sick units } & TYP & 23 & 86.67 \\
& MTDF & - & - \\
\hline Improvement in & TYP & 22 & 73.33 \\
marketing facilities & MTDF & 24 & 80 \\
\hline
\end{tabular}

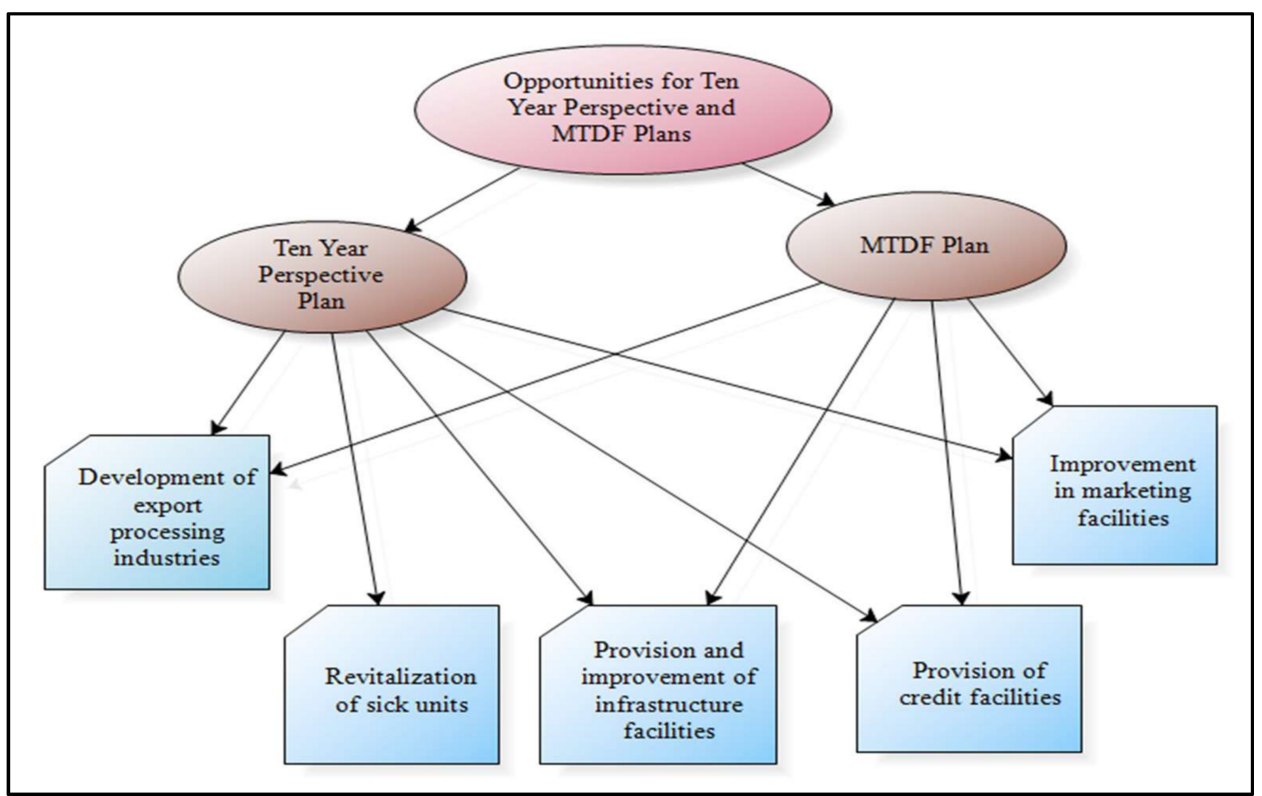

Figure 8. Cognitive Map of Opportunities of Ten-Year Perspective and MTDF Plans for Agro-based Industrial Development.

The opportunities of both development plans for agro-based development include:

i. More than $76 \%$ of key informants claimed that both development plans suggested the development of processing units of export-oriented products (see Table 6 and Figure 8). In this regard, the ten-year perspective and MTDF developed proposals for the enhancement of export-oriented industries in different cities (ABI Cases 11; 17; 28).

ii. More than $60 \%$ of agro-based key informants responded that both the development plans proposed providing adequate infrastructure facilities for agro-based industries (see Table 6 and Figure 8). In this regard, both development plans proposed providing farm to market roads, space to establish business in urban areas and provision of utilities in industrial estates (ABI Cases $1 ; 3 ; 15 ; 30$ ).

iii. More than $83 \%$ of key informants claimed that both development plans had proposed to provide credit facilities to the agro-based developers (see Table 6 and Figure 8). Therefore, both plans suggested establishing Khushali Banks to provide loans to unemployed persons for setting agro-based and cottage industries (ABI Cases $1 ; 11 ; 22 ; 27$ ).

iv. About $87 \%$ of key informants claimed that the ten-year perspective plan also presented opportunity for the revitalization of sick industrial units (ABI Cases 12; 27) (see Table 6 and Figure 8). 
v. More than $73 \%$ of key informants also claimed that the ten-year perspective and MTDF plans suggested providing and improving marketing facilities for agro-based industries (ABI Cases 18; 23) (see Table 6 and Figure 8).

\subsubsection{Threats for Ten-Year Perspective and MTDF Plans}

The analysis of the gathered data revealed two types of threats in ten-year perspective and medium-term development plans for agro-based industrial development: the planning system and cross-border threats. The details about these threats in each plan based on the responses of the key informant interviewees are described in Table 7 and Figure 9.

Table 7. Content Analysis Coding Results of Threats for Ten-Year Perspective and Medium-Term Development Framework Plans.

\begin{tabular}{|c|c|c|c|c|}
\hline $\begin{array}{c}\text { Threats } \\
\text { (Main-Themes) }\end{array}$ & Threats (Sub-Themes) & $\begin{array}{l}\text { Development } \\
\text { Plans }\end{array}$ & $\begin{array}{c}\text { No of } \\
\text { Respondents }\end{array}$ & $\begin{array}{l}\text { Percentage } \\
(\mathrm{n} \times 100 / 30)\end{array}$ \\
\hline \multirow{4}{*}{$\begin{array}{l}\text { Planning system } \\
\text { threats for ten-year } \\
\text { perspective and } \\
\text { medium-term } \\
\text { development plans }\end{array}$} & \multirow{2}{*}{$\begin{array}{l}\text { Weak strategic infrastructure } \\
\text { facilities in secondary cities }\end{array}$} & TYP & 23 & 76.67 \\
\hline & & MTDF & 24 & 80 \\
\hline & \multirow{2}{*}{$\begin{array}{l}\text { Centralized system of } \\
\text { development plans }\end{array}$} & TYP & 24 & 80 \\
\hline & & MTDF & 24 & 80 \\
\hline \multirow{6}{*}{$\begin{array}{l}\text { Cross-border } \\
\text { threats for ten-year } \\
\text { perspective and } \\
\text { medium-term } \\
\text { development plans }\end{array}$} & \multirow{2}{*}{ Prolong issue of Afghanistan } & TYP & 23 & 76.67 \\
\hline & & MTDF & 24 & 80 \\
\hline & \multirow{2}{*}{$\begin{array}{l}\text { Weak law and order } \\
\text { situation due to presence of } \\
\text { Afghan refugees }\end{array}$} & TYP & 25 & 83.33 \\
\hline & & MTDF & 26 & 86.66 \\
\hline & \multirow{2}{*}{$\begin{array}{l}\text { Diversion of } \\
\text { development budget }\end{array}$} & TYP & 25 & 83.33 \\
\hline & & MTDF & 26 & 86.66 \\
\hline
\end{tabular}

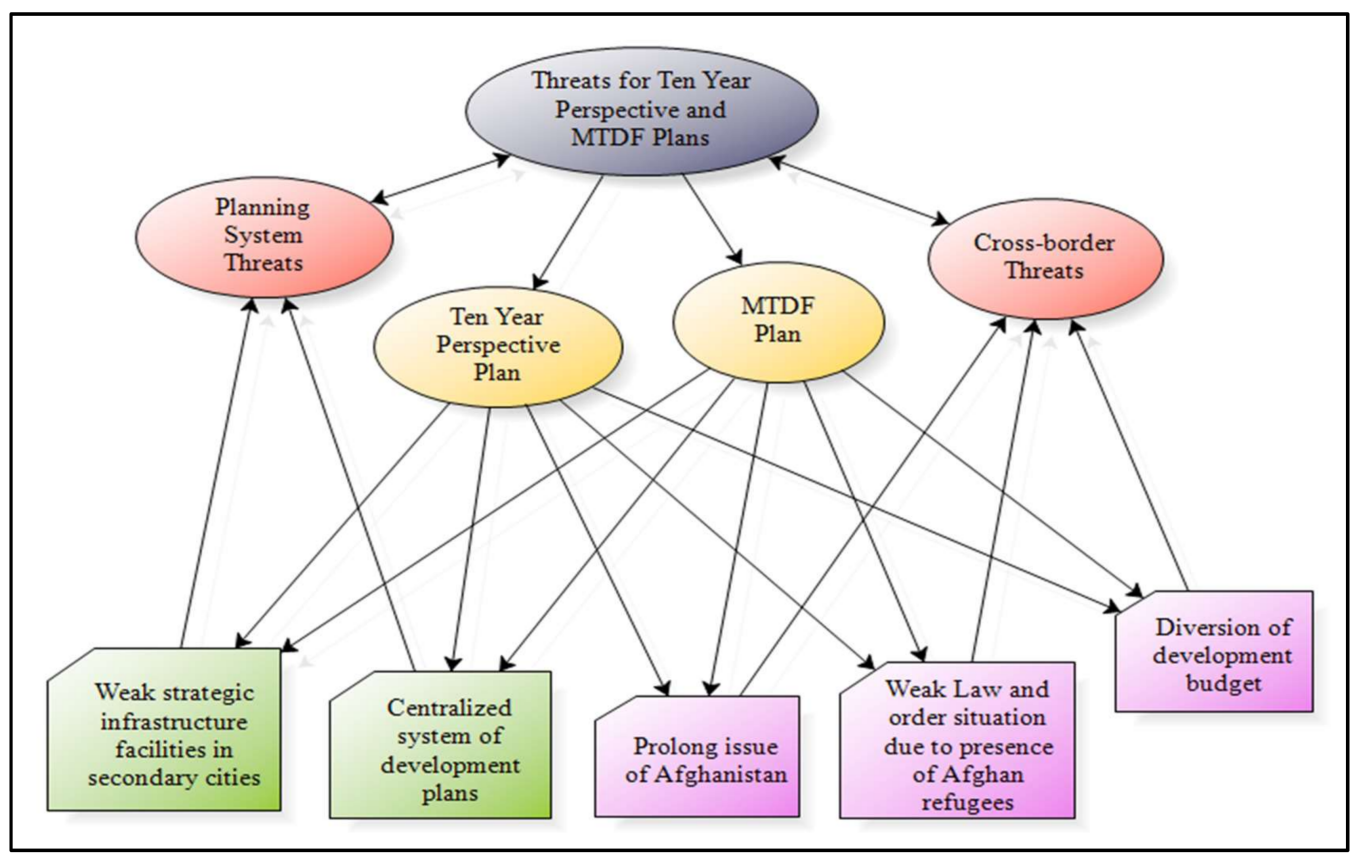

Figure 9. Cognitive Map of Threats of Ten-Year Perspective and MTDF Plans for Agro-Based Industrial Development. 
1. Threats in Planning System

The analysis of key informant interview data revealed two types of common threats present in both ten-year perspective and medium-term development framework plans for agro-based industrial development (see Table 7 and Figure 9). The planning system threats to both development plans include:

i. More than $76 \%$ of key informants claimed that both development plans failed to develop strategic infrastructure essential for agro-based industries in secondary cities of Sindh Province (see Table 7 and Figure 9). Although the plans proposed providing marketing facilities for agro-based industrial development, due to provincial government reliance on federal government for the release of the budget, there was lack of credit services for medium and small industries investors (ABI Cases $5 ; 17 ; 24)$. Many unpaid debts on textile and sugar industries were written-off (ABI Cases 2; 7). The marketing facilities essential for agro-based industrial development were also planned to be implemented in the metropolitan cities (ABI Cases 18; 21).

ii. Eighty percent of key informants of agro-based sectors claimed that the major threat to development plans is the centralized planning system of Pakistan (see Table 7 and Figure 9). In a centralized system, the federal government has powers to take development decisions and release of capital (ABI Cases 6; 13; 29). Therefore, if the federal government is not willing to carry out a development program in any part of the country, it can prohibit that program (ABI Cases $16 ; 27 ; 22)$.

2. Cross-Border Threats

The analysis of interview data revealed three types of cross-border threats present in ten-year perspective and medium-term development framework plans for agro-based industrial development (see Table 7 and Figure 9). The cross-border threats to both the development plans include:

i. More than $76 \%$ of key informants believed the prolonged issue of Afghanistan is a major cross-border threat for Pakistan (see Table 7 and Figure 9). After 9/11 incidence, due to America's attack in Afghanistan, the Afghan refugees started migrating to Pakistan (ABI Cases 10; 15; 18). That created obstacles in the many development works and burdened Pakistan's economy (ABI Cases $6 ; 18 ; 20 ; 30$ ).

ii. More than $83 \%$ of key informants claimed that the migration of Afghan refugees created law and order problems in Pakistan (see Table 7 and Figure 9). The American attacks in Afghanistan and at the border areas (some parts of Northern areas) and presence of Afghan Taliban worsened the law and order conditions in the northern areas of Pakistan (ABI Cases 2; 4; 8). Many innocent peoples were also killed in those attacks (ABI Cases 14; 20; 27).

iii. More than $83 \%$ of key informants claimed that, during ten-year perspective and MTDF plans, the development budget was used for defense activities and on the accommodation of Afghan refugees in Pakistan (see Table 7 and Figure 9). The migration of Afghan refugees created a heavy burden on Pakistan economy (ABI Cases 10; 11; 21). As a result, Pakistani government was forced to divert the development budget for the accommodation of Afghan refugees and defense activities (ABI Cases $1 ; 2 ; 13)$.

\section{Discussion}

The analysis of the ten-year perspective and MTDF development plans revealed that Pakistan has a centralized system for planning strategies, as well as sector-based policies. In a centralized planning system, the federal government has full authority to make decisions about development plans and to allocate the budget accordingly. Therefore, the federal government can prohibit any development program in any part of the country with its authority. The provincial governments have no autonomy to initiate any development work and heavily rely on the federal government for the planning and implementation of plans [32]. 
The results discussed in Section 5 revealed that the centralized system of development plans have resulted in planning strategy gaps in both development plans, which are discussed below.

\subsection{Lack of Interest in Agro-Based Industrial Development in Secondary Cities of the Sindh Province}

Based on the results, the ten-year perspective plan proposed planning strategies for agro-based industrial development. However, the medium-term development framework plan failed to present planning strategies for small and medium agro-based industrial development for the secondary cities of the Sindh Province. As the federal ministries prepare the plans, they always give priority to the development of textile and sugar industries. The reason is that Karachi, Faisalabad, Gujranwala and other metropolitan cities' industries are dominated by textile industry. Therefore, most of the planning strategies also emphasize the development of these industries. Much of the development budget is also allocated for their development (ABI Cases 10; 12; 16; 22, 28).

\subsection{Federal Government Autonomy for Development Budget}

One major weakness behind the implementation of the development plans was the provincial institutions' dependency on the federal government for the release of finance for plan implementation which applied in this centralized planning system. The federal government only released development funds to those programs which are considered favorable. Consequently, the ten-year perspective and MTDF plans were not implemented due to the provincial and local governments' reliance on the federal government for the release of funds; the influence of cross-border issues; and a worsening law and order situation in Pakistan, which, together, have taken away a major part of the development budget for defense purposes. This reliance also led to the lack of coordination between federal and provincial institutions.

\subsection{Absence of Strategic Infrastructure in Secondary Cities in the Sindh Province}

The results revealed that the federal government was more focused on and concerned about the development of metropolitan cities. Both development plans presented planning strategies for the provision of infrastructure facilities for agro-based industrial development. However, as discussed in Section 5.1, the federal government prioritized the development of textiles and sugar industries (mostly established in metropolitan cities). In addition, as described in Section 5.2, the federal government of Pakistan has autonomy for the development budget and decision powers. Therefore, infrastructure facilities were mostly provided in the agro-based industrial sites that are in and nearby to metropolitan areas. The result has been a lack of planning strategies to provide strategic infrastructure and to foster agro-based development in secondary cities.

\subsection{Cross-Border Issues}

After the 9/11 incidents in the United States of America (USA), the United States (US) army started the war in Afghanistan and many Afghani migrants shifted to Pakistan. The resistance to the US occupation spread to the autonomous areas of Pakistan bordering Afghanistan. This also worsened the law and order situation in different parts of Pakistan and reduced the number of foreign tourists (ABI Cases 3; 6; 9; 14; 24; 30). In addition, the migration of Afghan refugees to Pakistan heavily burdened the Pakistani economy. Consequently, the federal government spent $70-80 \%$ of the development budget for defense purposes and in the accommodation of these refugees. Due to this cross-border war and terrorist attacks, Pakistan has lost US\$11.16 billion of earnings in 2014-2015 from exports, foreign investment, tax collection, physical infrastructure and other activities [57].

\section{Conclusions}

The aim of this study was to explore and identify the planning strategy gaps in the ten-year perspective and medium-term development framework plans for agro-based industrial development 
in secondary cities of Sindh Province, Pakistan. It is concluded from above findings that the ten-year perspective plan presented the strategies for agro-based industries in secondary cities. The MTDF plan presented strategies for the upgrade of textile and sugar industries. However, the results in Section 5 revealed that weaknesses and threats the national development plans mostly faced were due to centralized planning system and planning approach of the development plans. Unfortunately, due to centralized system, the long-term and medium-term development plans in Pakistan are prepared at national level. Only annual plans are prepared at provincial level. There is an absence of long-term and medium-term planning system at provincial level. This planning gap has led to the problems of provincial dependency on federal institutions for the development and implementation of programs and use of development funds for other purposes. The ultimate remedy to avoid the drawbacks of the centralized planning system is the decentralization of powers to the provincial government. The provinces should have the autonomy to develop their own development plans.

Due to centralized planning system, the planning vision of the long-term and medium-term development plans were focused towards the development of metropolitan cities (ABI Cases 11; 22; 28). The metropolitan cities of Pakistan are dominated by textile and sugar industries. Therefore, the federal government have always prioritized the development of textile and sugar agro-based industries (ABI Cases 5; 17; 29). This has led towards the absence of planning strategies for agro-based industrial development and strategic infrastructure facilities in secondary cities of Sindh.

There is no doubt that textile and sugar are major export based industries. However, there are sufficient numbers of textile industries in Sindh Province and Pakistan to cater to the local needs and export demands (ABI Cases 19; 21; 27). In addition, these types of industries require heavy investment. In contrast, light and medium industries such as food processing, dairy products, pulses, dates processing, etc. do not require heavy investment, although these products are highly valued in other countries. Furthermore, light and medium industries help in creating more jobs and investment opportunities, sustainably utilize the local agricultural products and help in boosting the local economy of cities and regions. Karachi and Hyderabad Cities of Sindh Province are already facing the problems of urban sprawl, overcrowding, rural migration, environmental degradation due to heavy industrial development and worsening law and order situation. As a result, their industrial areas have come to a static point. However, the secondary cities have room for agro-based and other industrial development. Siddiqui (2011) and Anjum (2013) also suggested in their studies that the development of agro-based industries in secondary could improve the consumption level of the rural poor and generate more employment opportunities [4,13].

Thus, by considering these findings, the study arrived at the conclusion that the current planning system of Pakistan needs decentralization. Therefore, it is required that, instead of annual plans, the provinces should have the autonomy to develop their own development plans. It is also concluded that the planning vision of the development plans also needs to be transformed. The focus of the plans should be to develop small and medium agro-based industries in secondary cities of this province. Through transformation of planning system and development plans, the secondary cities of Sindh Province can be economically stabilized. The other three provinces of Pakistan (Punjab, Balochistan, and Khyber Pakhtunkhuwa) can also adopt the same strategies in their development plans to develop their secondary cities. Additionally, this can lead towards the strengthening of the local and regional economic development in Sindh and other provinces of Pakistan. Furthermore, these strategies can help in avoiding the uneven attention given to megacities and bringing the balanced system of cities in Sindh and other provinces by reducing migration to metropolitan cities for employment purposes.

To the best of the researcher's knowledge, this study is one of few that studied the planning strategies gaps of national development plans in bringing agro-based industrial development in secondary cities specifically in Sindh Province context. However, this research has a few limitations. The study undertook key informant interviews only with officials from the agro-based industrial sector working in the Sindh Province. However, it would also be beneficial to interview key informants from 
agro-based sectors working in federal ministries to get their views for further illustrative insights about the deficiencies in five-year plans.

Acknowledgments: The author(s) received no financial support for the research, authorship, and publication of this article.

Author Contributions: The different knowledge and experience of each author has equally contributed to the development and final version of the article. All authors collectively designed the methodology, performed the data collection, analyzed the data and wrote the paper together and with equal responsibility.

Conflicts of Interest: The authors declare no conflict of interest.

\section{References}

1. Partridge, M.; Olfert, M.R.; Alasia, A. Canadian cities as regional engines of growth: Agglomeration and amenities. Can. J. Econ. 2007, 40, 39-68. [CrossRef]

2. $\mathrm{Wu}$, J.J.; Gopinath, M. What causes spatial variations in economic development in the United States? Am. J. Agric. Econ. 2008, 90, 392-408. [CrossRef]

3. Berdegue, J.A.; Carriazo, F.; Jara, B.; Modrego, F.; Soloaga, I. Cities, territories and inclusive growth: Unraveling urban-rural linkage in Chile, Colombia and Mexico. World Dev. 2015, 73, 56-71. [CrossRef]

4. Anjum, A. Economics of urbanization. In The Urban Gazette; Urban Unit, Planning and Development Department, Government of Punjab: Lahore, Pakistan, 2013.

5. Song, L.K. Southeast Asian Secondary Cities: Frontiers of Opportunity and Challenges; MIT, Community Innovators Lab (CoLab), Massachusetts Institute of Technology: Boston, MA, USA, 2013.

6. Lochner, M.; Ronnie, D.; Etienne, N. Secondary Cities and Development; Routledge, Taylor \& Francis Group: London, UK, 2016.

7. Juan, E. Foreword on Managing System of Secondary Cities: Policy Responses in International Development; Cities Alliance: Brussels, Belgium, 2014; p. 2.

8. Recasens, X.; Alfranca, O.; Maldonado, L. The adaptation of urban farms to cities: The case of the Alella wine region within the Barcelona metropolitan region. Land Use Policy 2016, 56, 158-168. [CrossRef]

9. Rabbi, A.; Mamoon, D. Short Term Versus Long Term Economic Planning in Pakistan: The Dilemma; MPRA Paper No. 76114; MPRA: Munich, Germany, 2017; pp. 13-47.

10. Wilkinson, J.; Rocha, R. Agro-Industries for Development; Food and Agriculture Organization and United Nations Industrial Development Organization: London, UK, 2009; Chapter 3; pp. 46-88.

11. Edoumiekumo, S.G.; Audu, N.P. The Impact of Agriculture and Agro-Based Industries on Economic Development in Nigeria: An Econometric Assessment. J. Res. Natl. Dev. 2009, 7, 1-8. Available online: http:/ / www.transcampus.org/JORINDV7Jun2009/JournalsV7NO1Jun200914.html (accessed on 12 January 2018).

12. Pakistan Bureau of Statistics. Pakistan Statistical Year Book; Statistics Division, Government of Pakistan: Islamabad, Pakistan, 2017; pp. 251-258.

13. Siddiqui, K. Experiences of capitalism in India and Pakistan. Res. Appl. Econ. 2011, 3, 1-49. [CrossRef]

14. Planning and Development Department, Government of Sindh. Directorate of Urban Policy and Strategic Planning; Planning and Development Department, Government of Sindh: Karachi, Pakistan, 2017.

15. Robert, B.H.; Hohmann, R.P. The System of Secondary Cities: The Neglected Divers of Urban Economies; Cities Alliance: Kampala, Uganda, 2014.

16. Rondinelli, D.A. Dynamics of growth of secondary cities in developing countries. Geogr. Rev. 1983, 73, 42-57. [CrossRef]

17. Robert, B.H. Managing System of Secondary Cities: Policy Responses in International Development; Cities Alliance: Brussels, Belgium, 2014; Chapter 6; pp. 66-87.

18. European Spatial Planning Observation Network and European Institute of Urban Affairs. Second-Tier Cities and Territorial Development in Europe: Performance, Policies and Prospects; Liverpool Jhon Moores University: Liverpool, UK, 2012; p. 3.

19. MacDonald, S. Secondary Cities Are an Untapped Resource. Penang Monthly, 2012. Available online: http:// penangmonthly.com/secondary-cities-are-anuntapped-resource/ (accessed on 28 January 2013). 
20. Richardson, H.N. City Size and National Spatial Strategies in Developing Countries; World Bank Staff Working Paper 52; World Bank: Washington, DC, USA, 1977; pp. 45-80.

21. Al-Naser, A.S. The Need for Developing Policies and Guidelines for Future Growth of Secondary Cities in Saudi Arabia: A Case of Hofuf; Department of City and Regional Planning, University of Pennsylvania: Philadelphia, PA, USA, 1989; pp. 1-30.

22. Shakir, M.M.; Ahmed, S. Economic functioning of secondary cities of Pakistan and its integration with physical land use: Case of Larkana and Mansehra. J. Archit. Plan. Res. 2014, 16, 33-54.

23. Baker, J. Rural-Urban Dynamics in Francophone Africa; Gotab: Stockholm, Sweden, 1997.

24. Sara, F.A. Urban Municipal Services: Sindh Secondary Cities Urban Sector Assessment; Sindh Basic Urban Services Project; Government of Sindh and Asian Development Bank: Karachi, Pakistan, 2007.

25. Government of Pakistan. Planning Commission; Ministry of Planning, Development and Reforms, Government of Pakistan: Islamabad, Pakistan, 2017.

26. Planning Commission. Ten Year Perspective Plan (2001-2011) and Three Year Development Programme (2001-2004); Planning Commission, Government of Pakistan: Islamabad, Pakistan, 2001.

27. Planning Commission. Medium Term Development Framework (2005-2010); Planning Commission, Government of Pakistan: Islamabad, Pakistan, 2005.

28. Knox, P.L.; Taylor, P.J. Worlds Cities in World-System; Cambridge University Press: Cambridge, UK, 1995.

29. Kumar, R. Urbanization and Secondary Cities: Forms; Trends; Potentials; Challenges. In Proceedings of the Seminar on Urban and Regional Planning, Karachi, Pakistan, 10 December 2012; NED University of Engineering and Technology: Karachi, Pakistan, 2012.

30. Bolay, J.C.; Rabinovich, A. Intermediate cities in Latin America risk and opportunities of coherent urban development. Cities 2004, 21, 407-421. [CrossRef]

31. Abadzic, A.; Umihanic, B.; Cebic, M. Analysis of methodology and models of strategic planning of local development in Bosnia and Herzegovinian. J. Econ. Bus. 2012, 2, 15-25.

32. Angel, S. Planet of Cities; MA Lincoln Institute of Land Policy: Cambridge, UK, 2012.

33. Biswas, A.K.; Kris, H. Why India's Secondary Cities Are the Future. Available online: https:// thirdworldcentre.org/communication-media/why-indias-secondary-cities-are-the-future (accessed on 16 October 2017).

34. Williams, J.F. The role of secondary cities in rapidly industrializing countries: The example of Kaohsiung, Taiwan. GeoJournal Libr. 2004, 75, 225-241.

35. Christiansen, L.; Todo, Y. Poverty Reduction during the Rural-Urban Transformation: The Role of the Missing Middle; Policy Research Working Paper Series 6445; World Bank: Washington, DC, USA, 2013.

36. Vachal, K. Economic Growth of Nonmetropolitan and Agricultural Region Cities; School of Public Policy, George Mason University: Fairfax, VA, USA, 2005; p. 4.

37. Pakistan Bureau of Statistics. Labor Force Statistics; Ministry of Labor, Manpower and Overseas Pakistanis Division, Government of Pakistan: Islamabad, Pakistan, 2017. Available online: http:/ /www.pbs.gov.pk/ content/labour-force-statistics (accessed on 17 August 2017).

38. Industries and Commerce Department. List of SITE Areas in Sindh Province; Government of Sindh: Karachi, Pakistan, 2017. Available online: https://www.site.com.pk/wordpress/?page_id=108 (accessed on 20 November 2017).

39. Robson, C. Real World Research: A Resource for Social Scientist and Practitioner-Researchers, 3rd ed.; Blackwell: Oxford, UK, 2011.

40. Saunders, M.; Lewis, P.; Thornhill, A. Research Methods for Business Students, 5th ed.; Prentice Hall: Harlow, UK, 2009.

41. Higgs, J.; Tichen, A.; Horsfall, D.; Bridges, D. Creative Spaces for Qualitative Researching: Living Research; Sense Publishers: Rotterdam, The Netherland, 2011.

42. Bryman, A. Social Research Methods; Routledge: New York, NY, USA, 2008.

43. Lichtman, M. Understanding and Evaluating Qualitative Educational Research; Thousand Oaks, SAGE: Los Angeles, CA, USA, 2011.

44. USAID. Conducting Key Informant Interviews: Performance, Monitoring \& Evaluation Tips; USAID Center for Development Information and Evaluation: Washington, DC, USA, 1996. Available online: http:/ / pdf.usaid. gov/pdf_docs/PNABS541.pdf (accessed on 23 August 2017).

45. Bowen, A.G. Document analysis as a qualitative research method. Qual. Res. J. 2009, 9, 27-40. [CrossRef] 
46. Pact, Inc. Field Guide for Evaluation: How to Develop an Effective Terms of Reference; Pact: Washington, DC, USA, 2014. Available online: http:/ / www.pactworld.org (accessed on 23 August 2017).

47. Chua, Y.P. Mastering Research Methods; McGraw-Hill Education (Malaysia) Sdn. Bhd: Kuala Lumpur, Malaysia, 2012.

48. Cohen, L.; Manion, L.; Morrison, K. Research Methods in Education; Routledge: Abington, MA, USA, 2011.

49. Berg, B.L.; Lune, H. Qualitative Research Methods for the Social Sciences; Pearson: Boston, MA, USA, 2004; Volume 5.

50. Karppi, I.; Kokkonen, M.; Smith, K.L. SWOT-Analysis as a Basis for Regional Strategies; Nordregio Working Paper; Nordic Centre for Spatial Development: Stockholm, Sweden, 2001.

51. Tsenkova, S. SWOT Analysis of Sofia's Economy, Infrastructure and Spatial Planning Issues; Infrastructure Sector Unit, World Bank and Europe and Central Asia Region: Washington, DC, USA, 2002.

52. Tsenkova, S. Venturing into unknown territory: Strategic spatial planning in post-communist cities. Urbani Izziv 2011, 22, 83-99. [CrossRef]

53. Bazeley, P. Qualitative Data Analysis with Nvivo; SAGE Publications Ltd.: Los Angles, CA, USA, 2007.

54. Mayring, P. Qualitative Content Analysis. Qual. Soc. Res. 2000, 1. Available online: http:/ /217.160.35.246/ fqs-texte/2-00/200mayring-e.pdf (accessed on 24 August 2017).

55. White, M.D.; Marsh, E.E. Content analysis: A flexible methodology. Libr. Trends 2006, 55, 22-45. [CrossRef]

56. Stuckey, H.L. The Second Step in Data Analysis: Coding Qualitative Research Data. Methodol. Issues Social Health Diabetes Res. 2015, 3, 7-10. [CrossRef]

57. Pakistan Economic Survey (2011-2012); Ministry of Finance, Government of Pakistan: Islamabad, Pakistan, 2012; pp. 161-175. Available online: http://www.finance.gov.pk/survey_1112.html (accessed on 25 September, 2017).

(C) 2018 by the authors. Licensee MDPI, Basel, Switzerland. This article is an open access article distributed under the terms and conditions of the Creative Commons Attribution (CC BY) license (http:/ / creativecommons.org/licenses/by/4.0/). 